\title{
Measurements of $\mathrm{N}_{2} \mathrm{O}_{5}, \mathrm{NO}_{2}$, and $\mathrm{O}_{3}$ east of the San Francisco Bay
}

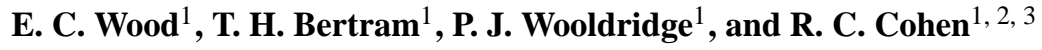 \\ ${ }^{1}$ Department of Chemistry, University of California, Berkeley, California \\ ${ }^{2}$ Department of Earth and Planetary Sciences, University of California, Berkeley, California \\ ${ }^{3}$ Energy and Environment Technologies Division, Lawrence Berkeley National Laboratory, Berkeley, California
}

Received: 13 September 2004 - Published in Atmos. Chem. Phys. Discuss.: 15 October 2004

Revised: 21 January 2005 - Accepted: 8 February 2005 - Published: 15 February 2005

\begin{abstract}
We report in situ measurements of $\mathrm{N}_{2} \mathrm{O}_{5}, \mathrm{NO}_{2}$, and $\mathrm{O}_{3}$ in Contra Costa County, California during January 2004. Mixing ratios of $\mathrm{N}_{2} \mathrm{O}_{5}$, an intermediate compound in the atmosphere's nocturnal cleansing process, ranged up to $200 \mathrm{pmol} / \mathrm{mol}$ at night. The highest $\mathrm{N}_{2} \mathrm{O}_{5}$ concentrations were correlated with low $\mathrm{O}_{3}$ and high $\mathrm{NO}_{2}$ concentrations. The calculated steady state lifetime for $\mathrm{N}_{2} \mathrm{O}_{5}$ ranged from 5 to 30 min. The total $\mathrm{HNO}_{3}$ produced by $\mathrm{N}_{2} \mathrm{O}_{5}$ hydrolysis over a $14 \mathrm{~h}$ night was comparable to ambient $\mathrm{NO}_{2}$ concentrations, and is estimated to be a factor of nine bigger than the $\mathrm{HNO}_{3}$ produced during the day.
\end{abstract}

\section{Introduction}

The nitrate radical $\left(\mathrm{NO}_{3}\right)$ and dinitrogen pentoxide $\left(\mathrm{N}_{2} \mathrm{O}_{5}\right)$ are uniquely important to the nocturnal chemistry of the troposphere. $\mathrm{NO}_{3}$ is produced by the reaction of nitrogen dioxide $\left(\mathrm{NO}_{2}\right)$ with ozone $\left(\mathrm{O}_{3}\right)$ :

$\mathrm{NO}_{2}+\mathrm{O}_{3} \stackrel{\mathrm{k}_{1}}{\longrightarrow} \mathrm{NO}_{3}+\mathrm{O}_{2}$

Reaction (1) is slow: at $278 \mathrm{~K}, \mathrm{k}_{1}$ is equal to $1.8 \times 10^{-17} \mathrm{~cm}^{3}$ molecule ${ }^{-1} \mathrm{~s}^{-1}$ (Sander et al., 2003), resulting in a 1/e lifetime for $\mathrm{NO}_{2}$ at $30 \mathrm{nmol} / \mathrm{mol}$ (parts per billion by volume, ppbv) of $\mathrm{O}_{3}$ of $24 \mathrm{~h}$.

An equilibrium is established between $\mathrm{NO}_{2}, \mathrm{NO}_{3}$, and $\mathrm{N}_{2} \mathrm{O}_{5}$ on timescales of a few minutes:

$\mathrm{NO}_{2}+\mathrm{NO}_{3}+\mathrm{M} \longleftrightarrow \mathrm{N}_{2} \mathrm{O}_{5}+\mathrm{M}$

In moderately cold and/or polluted conditions (i.e. high $\left[\mathrm{NO}_{2}\right]$ ), this equilibrium is strongly shifted to the right. For example, at $10^{\circ} \mathrm{C}$ and 2 ppbv of $\mathrm{NO}_{2}$, the $\left[\mathrm{N}_{2} \mathrm{O}_{5}\right]$ : $\left[\mathrm{NO}_{3}\right]$ ratio at equilibrium is 11 . This rapid removal of a second

Correspondence to: R. C. Cohen

(cohen@cchem.berkeley.edu)
$\mathrm{NO}_{2}$ molecule reduces the effective lifetime of $\mathrm{NO}_{2}$ to $12 \mathrm{~h}$. During the day, $\mathrm{NO}_{3}$ is photolyzed (overhead photolysis rate $\approx 0.2 \mathrm{~s}^{-1}$ ) and reacts rapidly with nitric oxide (NO), thus limiting $\mathrm{NO}_{3}$ mixing ratios to well below $1 \mathrm{nmol} / \mathrm{mol}$ (parts per trillion by volume, pptv). In contrast, at night $\mathrm{NO}_{3}$ mixing ratios of up to a few hundred pptv have been observed in urban plumes (Wayne et al., 1991) and mixing ratios up to $40 \mathrm{pptv}$ are common in more remote regions (Brown et al., 2003a; Carslaw et al., 1997; Geyer et al., 2001; Simpson, 2003; Wayne et al., 1991). $\mathrm{N}_{2} \mathrm{O}_{5}$ mixing ratios of up to 3 ppbv have been observed near Boulder, Colorado (Brown et al., 2003a). In northern latitudes (Simpson, 2003) and in the marine boundary layer (Brown et al., 2004) $\mathrm{N}_{2} \mathrm{O}_{5}$ mixing ratios of less than $0.1 \mathrm{ppbv}$ are more common.

The chemistry of $\mathrm{NO}_{3}$ and $\mathrm{N}_{2} \mathrm{O}_{5}$ affects the concentrations of volatile organic compounds (VOCs) and $\mathrm{NO}_{\mathrm{x}}$ $\left(\mathrm{NO}_{\mathrm{x}} \equiv \mathrm{NO}+\mathrm{NO}_{2}\right) . \mathrm{NO}_{3}$ reacts rapidly with alkenes and calculations suggest that $\mathrm{NO}_{3}$ is the predominant oxidant for some biogenic VOCs (Warneke et al., 2004; Wayne et al., 1991). $\mathrm{N}_{2} \mathrm{O}_{5}$ hydrolyzes on surfaces to form nitric acid $\left(\mathrm{HNO}_{3}\right)$ :

$\mathrm{N}_{2} \mathrm{O}_{5}+\mathrm{H}_{2} \mathrm{O}_{(\mathrm{l})} \stackrel{\text { heterogeneous }}{\longrightarrow} 2 \mathrm{HNO}_{3}$

The set of Reactions (1-3) is one of the major paths for the removal of $\mathrm{NO}_{\mathrm{x}}$ from the atmosphere. The sticking coefficient $(\gamma)$ for Reaction (3) varies from 0.02 for uptake onto $\mathrm{NaNO}_{3}$ aerosol (Mentel et al., 1999) to over 0.1 for uptake onto $\mathrm{H}_{2} \mathrm{SO}_{4}$ aerosol (Hanson and Ravishankara, 1991; Robinson et al., 1997). Measurements in a variety of locations have indicated that the $\mathrm{NO}_{2}$ removed at night by Reactions (1-3) can be comparable in magnitude to the loss of $\mathrm{NO}_{2}$ during the day by reaction with $\mathrm{OH}$ to form nitric acid (Heintz et al., 1996; Martinez et al., 2000).

Prior to 2000, atmospheric $\mathrm{N}_{2} \mathrm{O}_{5}$ had only been measured by long-path absorption spectroscopy in the stratosphere (Kunde et al., 1988; Rinsland et al., 1989; Sen et al., 1998; Toon et al., 1986; Zhou et al., 1997), and $\mathrm{NO}_{3}$

(C) 2005 Author(s). This work is licensed under a Creative Commons License. 


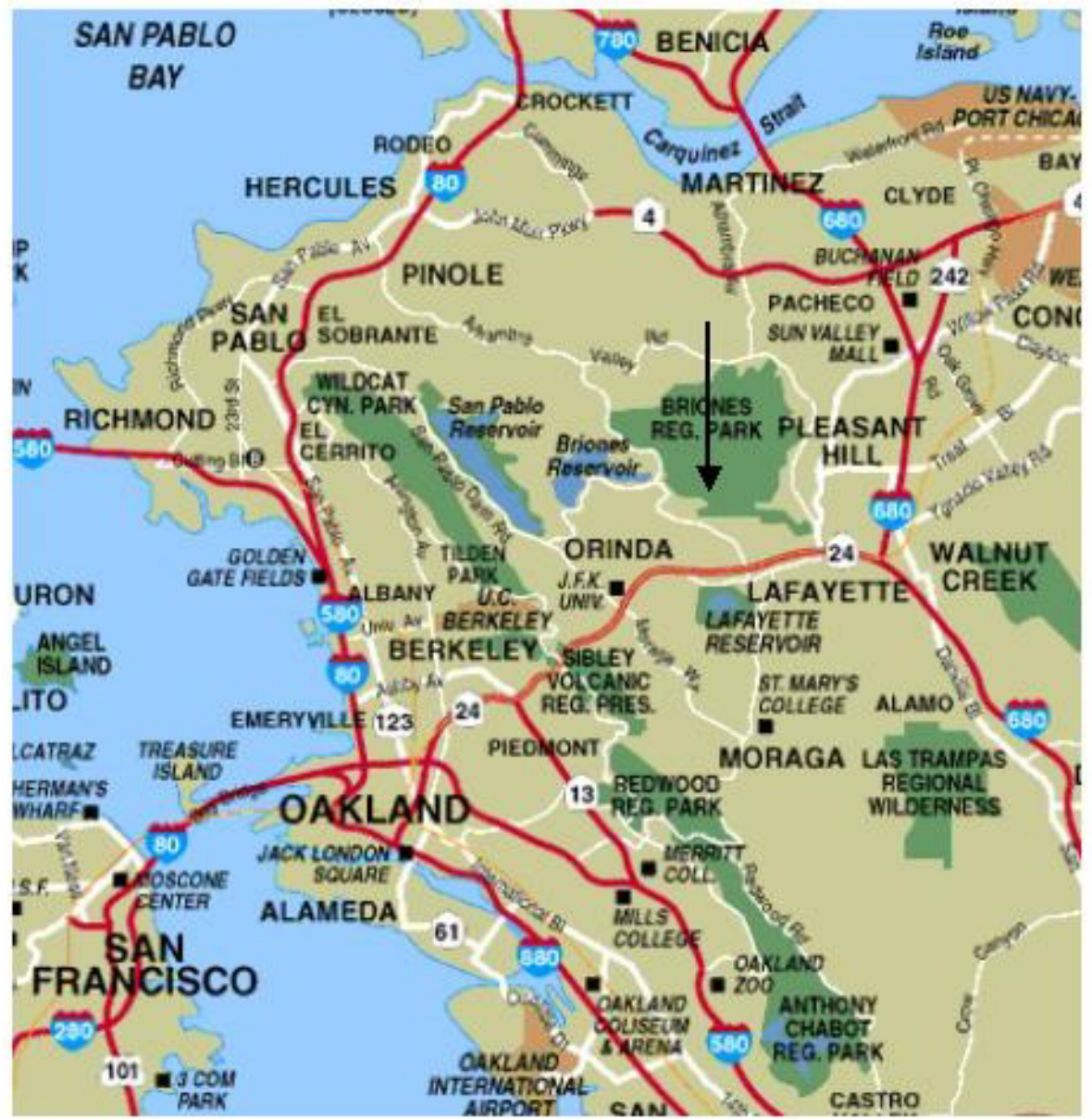

Fig. 1. Map of the greater San Francisco Bay Area. The Leuschner observatory is indicated by the arrow (adapted from http://www.sfgate. com/traveler).

had only been measured by Differential Optical Absorbance Spectrometry (DOAS) (Heintz et al., 1996; Platt and Heintz, 1994) and Matrix Isolation-Electron Spin Resonance Spectrometry (MI-ESR) (Geyer et al., 1999). More recently, in situ instruments based on Cavity Ring-Down Spectroscopy (CRDS) have been constructed (Brown et al., 2002; Simpson, 2003). These CRDS instruments have superior sensitivity to $\mathrm{NO}_{3}$ and have produced the first measurements of tropospheric $\mathrm{N}_{2} \mathrm{O}_{5}$. We recently described our approach to measurement of $\mathrm{NO}_{3}$ and $\mathrm{N}_{2} \mathrm{O}_{5}$ by laser-induced fluorescence (LIF) (Wood et al., 2003). In this manuscript we describe the first field test of this instrument.

\section{Experimental}

Concentrations of $\mathrm{N}_{2} \mathrm{O}_{5}, \mathrm{NO}_{2}, \mathrm{O}_{3}$, and meteorological data were measured at the Leuschner Astronomical Observatory on the University of California Russell Reservation in Contra Costa County, California $\left(37: 55: 06^{\circ} \mathrm{N}, 122: 9: 24^{\circ} \mathrm{W}\right.$, altitude $290 \mathrm{~m}$ ) during January 2004 (Fig. 1). The reservation is a 115 hectare site consisting of a mix of forest, woodland, chaparral, and grassland vegetation. To the north is the 2300 hectare Briones Regional Park. The city center of Lafayette, a suburban town $30 \mathrm{~km}$ northeast of San Francisco, is $4 \mathrm{~km}$ southeast of the site. Highway 24, on which there is moderate traffic at night, passes $3 \mathrm{~km}$ to the south of the site. Extending from the southwest to the northeast along highway 80 and highway 4 are a number of oil refineries and natural gas-fired power plants, at closest $10 \mathrm{~km}$ to the site.

\section{$2.1 \quad \mathrm{~N}_{2} \mathrm{O}_{5}$ measurements}

$\mathrm{N}_{2} \mathrm{O}_{5}$ was measured by LIF detection of $\mathrm{NO}_{3}$ after thermal dissociation to $\mathrm{NO}_{2}$ and $\mathrm{NO}_{3}$ :

$\mathrm{N}_{2} \mathrm{O}_{5}+\mathrm{M} \stackrel{\Delta}{\longrightarrow} \mathrm{NO}_{2}+\mathrm{NO}_{3}+\mathrm{M}$

using an instrument based on the prototype described in Wood et al. (2003). Although this method yields a measurement of the sum of ambient $\left[\mathrm{NO}_{3}\right]$ and $\left[\mathrm{N}_{2} \mathrm{O}_{5}\right]$, due to the high $\left[\mathrm{N}_{2} \mathrm{O}_{5}\right]:\left[\mathrm{NO}_{3}\right]$ ratios expected at the ambient temperatures and $\mathrm{NO}_{2}$ concentrations observed, we interpret all 
measurements as $\mathrm{N}_{2} \mathrm{O}_{5}$. For example, at $3^{\circ} \mathrm{C}$ and 5 ppbv of $\mathrm{NO}_{2}$ (typical conditions for the data presented in Sect. 3), the $\left[\mathrm{N}_{2} \mathrm{O}_{5}\right]$ : $\left[\mathrm{NO}_{3}\right]$ ratio, calculated from the equilibrium constant of Reaction (2), is $80 . \mathrm{NO}_{3}$ ranged from $0.5 \%-10 \%$ of the measured sum in this dataset, and was usually less than $5 \%$ of the sum.

The support equipment (e.g. gas tanks and computer) was located in the observatory and the laser, detection cell, electronics, and vacuum pumps were situated outside, $3 \mathrm{~m}$ from the observatory. Air was sampled at a height of $1.2 \mathrm{~m}$. A 6 standard liters/min (SLPM) flow of ambient air passed through a $22 \mathrm{~cm}$ section of $3 / 8^{\prime \prime}$ OD PFA Teflon tubing resistively heated to an external temperature of $190^{\circ} \mathrm{C}$. Sampled air had a $70 \mathrm{~ms}$ transit time in the heated region before passing through an $0.8 \mathrm{~mm}$ orifice into the detection region, which was held at 2 Torr $(2.7 \mathrm{mbar})$. Varing the inlet temperature from ambient to $200^{\circ} \mathrm{C}$ indicated that $\mathrm{N}_{2} \mathrm{O}_{5}$ was fully dissociated at $170^{\circ}$ under these conditions. The cell pressure was measured with a capacitance manometer (MKS).

Figure 2 depicts the optical cell and inlet of the instrument. $\mathrm{NO}_{3}$ was excited by $662 \mathrm{~nm}$ light from a high-power $(300 \mathrm{~mW})$, multi-mode (bandwidth $=0.3 \mathrm{~nm}$ ) InAlGaP diode laser in the $B^{2} \mathrm{E}^{\prime}(0000) \leftarrow X^{2} \mathrm{~A}_{2}^{\prime}(0000)$ band. An aspheric lens focused the diode output from the $1 \mu \mathrm{m} \times 150 \mu \mathrm{m}$ emitting strip to an $0.3 \mathrm{~cm}$ (horizontal) by $1 \mathrm{~cm}$ (vertical) rectangular spot at the center of the cell. The laser light entered the cell through a glass window mounted at $45^{\circ}$ located $20 \mathrm{~cm}$ from the center of the cell and exited through a similar glass window $13 \mathrm{~cm}$ from the center. Vertical slit geometric baffles were used to reduce laser scatter and to exclude ambient light from the cell. The laser power exiting the cell was monitored by a photodiode. The electric field vector of the laser light was aligned parallel to the detection axis in order to minimize the collection of Rayleigh, Raman, and other polarized scattered laser light. $\mathrm{NO}_{3}$ fluorescence was collected by a $55 \mathrm{~mm}$ focal length lens and passed through a $750 \mathrm{~nm}$ short-pass filter, an all dielectric $700 \mathrm{~nm}$ long-pass interference filter, and a second $700 \mathrm{~nm}$ long-pass interference filter which contained a layer of absorbing glass. The final filtered fluorescence was focused onto the photocathode of a thermoelectrically-cooled red-sensitive GaAs Hamamatsu H7421-50 photomultiplier tube (PMT).

The high laser power, single-pass design of this instrument had comparable sensitivity to the low laser power, multi-pass design of the prototype described in Wood et al. (2003). The background of this single-pass design $(\sim 100$ counts/s) was 14 times smaller than that of the prototype. The signal rate was half that of the prototype; the reduction in laser fluence due to foregoing a multi-pass alignment was almost compensated for by the increase in laser power. The poor beam quality of this laser precluded use of a multipass arrangement.

The instrument's background was measured by injection of $\mathrm{NO}$ into the inlet, which converts $\mathrm{NO}_{3}$ to $\mathrm{NO}_{2}$ :

$\mathrm{NO}+\mathrm{NO}_{3} \longrightarrow 2 \mathrm{NO}_{2}$
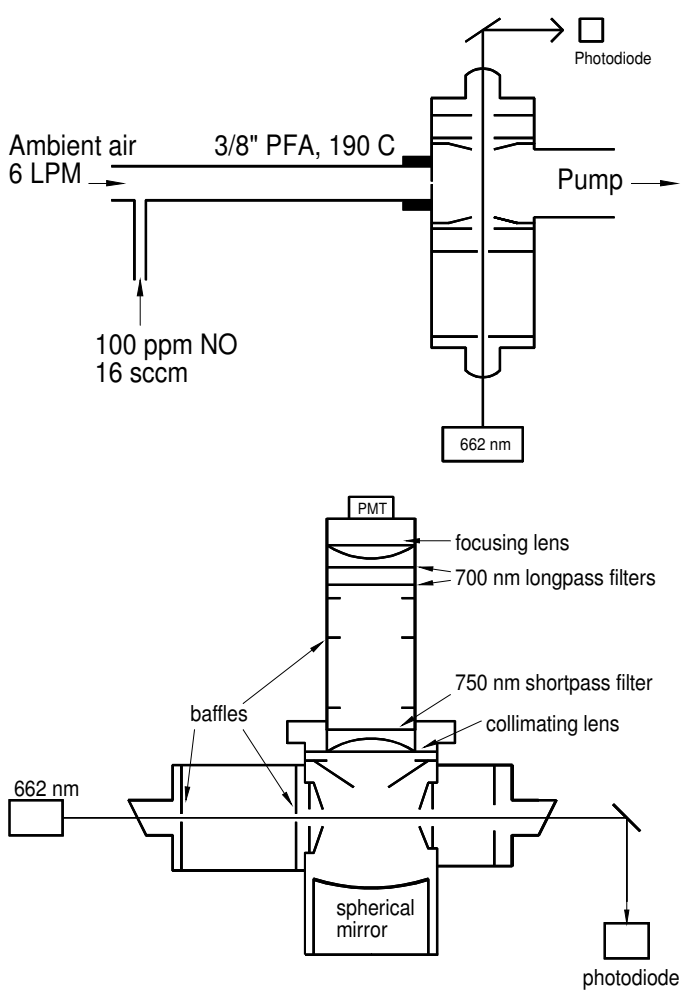

Fig. 2. (a) Schematic diagram of the $\mathrm{N}_{2} \mathrm{O}_{5}$ LIF instrument's gas flow and excitation axes. Ambient air passes through $22 \mathrm{~cm}$ of $3 / 8^{\prime \prime}$ OD PFA teflon tubing which is externally heated to $190^{\circ} \mathrm{C}$. After a $70 \mathrm{~ms}$ residence time, the air expands through a $0.8 \mathrm{~mm}$ orifice into the optical cell where the $\mathrm{NO}_{3}$ from the thermal decomposition of $\mathrm{N}_{2} \mathrm{O}_{5}$ is excited by $300 \mathrm{~mW}$ of $662 \mathrm{~nm}$ light from a diode laser. (b) Schematic diagram of the excitation and detection axes. $\mathrm{NO}_{3}$ fluorescence between 700 and $750 \mathrm{~nm}$ is imaged onto the photocathode of a cooled red-sensitive PMT. The spherical mirror acts as a retroreflector and almost doubles the optical collection efficiency of the optical cell. A series of geometric baffles and spectral filters reduces the background to 100 counts/s.

The NO (Scott Specialty Gas) flowed through a $\mathrm{FeSO}_{4}$ trap in order to convert impurity $\mathrm{NO}_{2}$ into NO. We used a 16 standard cubic $\mathrm{cm}^{3} / \mathrm{min}(\mathrm{sccm})$ flow of $100 \mathrm{ppmv}$ NO delivered through a mass flow controller (MKS) and a solenoid valve to a PFA tee at the mouth of the inlet. The concentration of $\mathrm{NO}$ used $(270 \mathrm{ppbv}$ after dilution into the main flow of $6000 \mathrm{sccm}$ ) was sufficient to react $>99 \%$ of the $\mathrm{NO}_{3}$ while reacting with less than $1 \%$ of ambient $\mathrm{O}_{3}$. The experimental procedure consisted of $10 \mathrm{~s}$ of background observation (with NO flowing into the inlet) followed by $15 \mathrm{~s}$ of $\mathrm{N}_{2} \mathrm{O}_{5}$ observation. Data from the first five of these $15 \mathrm{~s}$ were discarded to ensure no contamination of the data by leaking of NO into the ambient air flow. Standard additions of $\mathrm{N}_{2} \mathrm{O}_{5}(6 \mathrm{sccm}$, $1 \mathrm{ppmv}$ diluted into a total flow of $6000 \mathrm{sccm}$ ) confirmed that leaking of $\mathrm{NO}$ was negligible two seconds after the solenoid valve closed. There is a small amount of $\mathrm{NO}_{2}$ fluorescence following $662 \mathrm{~nm}$ excitation. Since $\mathrm{NO}_{2}$ is present during 
both the background and sampling periods, this is accounted for in the background measurement.

The instrument background was typically between 105 and 115 PMT counts/s, of which 5 were from the PMT dark current, 75 were from laser scatter, 20 were from $\mathrm{O}_{2}$ Stokes Raman scattering, and at most 1 was from $\mathrm{NO}_{2}$ fluorescence (at $20 \mathrm{ppbv}$ of $\mathrm{NO}_{2}$ ). The remainder were presumably from Mie scattering and/or fluorescence of ambient aerosol. This aerosol component was pressure-dependent and only observed while sampling ambient air and not "zero" air (medical grade compressed air). The magnitude and variance of this scattering was as much as seven times higher with the inlet set at ambient temperature than at $190^{\circ} \mathrm{C}$ and was highest during nights of high relative humidity. The high variability of this component of the background necessitated the $10 \mathrm{~s}$ off/15 s on measurement cycle described above. Measurements were not possible on occasional nights of visibly high optical extinction (e.g. fog) due to excessive noise in the background. Teflon membrane filters eliminated this aerosol scattering and transmitted over $98 \%$ of $\mathrm{N}_{2} \mathrm{O}_{5}$. However, with the filter in place the pressure of the cell decreased over time, indicating that deposition of significant amounts of particulate matter was clogging the filter. This pressure decrease was fast enough that use of the filter would have required hourly filter changes and raised questions about $\mathrm{N}_{2} \mathrm{O}_{5}$ transmission over time that were avoided by the fast backgroundsampling cycle.

By slowly increasing the pressure in the cell while sampling ambient air, this Mie scattering was quantified and served as a relative measurement of the ambient aerosol load. The slope of the plot of PMT counts $s^{-1}$ versus pressure varied from 12 counts $\mathrm{s}^{-1}$ Torr $^{-1}$ to 60 counts $\mathrm{s}^{-1}$ Torr $^{-1}$, of which 10 counts $\mathrm{s}^{-1}$ Torr $^{-1}$ were from $\mathrm{O}_{2}$ Raman scattering (measured with zero air overflowing the inlet). The slope obtained while overflowing the inlet with zero air was used to track changes in the calibration constant (see below).

The instrument was calibrated in the laboratory at the conclusion of the field campaign as described in Wood et al. (2003). A mixture of $\mathrm{N}_{2} \mathrm{O}_{5}$ and $\mathrm{NO}_{2}$ was delivered to the instrument's heated inlet and the resultant $\mathrm{NO}_{3}$ fluorescence was observed. The $\mathrm{NO}_{2}$ concentration was quantified by LIF using a $15 \mathrm{~mW}$, tunable diode laser at $408 \mathrm{~nm}$. The spectral modulation used with the $638 \mathrm{~nm}$ laser described in Wood et al. (2003) to distinguish the $\mathrm{NO}_{2}$ fluorescence from the $\mathrm{NO}_{3}$ fluorescence was unnecessary with this violet laser as $\mathrm{NO}_{3}$ does not fluoresce after excitation at $408 \mathrm{~nm}$ (Johnston et al., 1996). Finally, NO was added to the inlet and the increase in $\mathrm{NO}_{2}$ signal from the reaction of $\mathrm{NO}$ with $\mathrm{NO}_{3}$ was used to quantify the $\mathrm{NO}_{3}$ concentration. Heterogeneous losses of $\mathrm{NO}_{3}$ within the inlet were accounted for by this method of calibration since the $\mathrm{NO}_{3}$ was rapidly converted to $\mathrm{NO}_{2}$, which passes into the optical cell without losses. Heterogeneous losses of $\mathrm{N}_{2} \mathrm{O}_{5}$ were estimated to be negligible based on the the wall loss rate constant of $8 \times 10^{-3} \mathrm{~s}^{-1}$ measured by Simpson for $\mathrm{N}_{2} \mathrm{O}_{5}$ on $1 / 2^{\prime \prime}$ OD dry PFA tubing at
1 atm (Simpson, 2003). Differences in heterogeneous losses between laboratory and field conditions associated with humidity were expected to be small as the inlet air was kept hot and therefore at low relative humidity. Electronic quenching of excited $\mathrm{NO}_{3}$ by water vapor was shown to be no more significant than that by nitrogen or oxygen: during a standard addition of $\mathrm{N}_{2} \mathrm{O}_{5}$ to the inlet, no discernable difference in fluorescence $(<1 \%)$ was observed when the $\mathrm{N}_{2} \mathrm{O}_{5}$ flow $(10 \mathrm{sccm})$ was diluted with dry zero air or with ambient air of $95 \%$ relative humidity at $11^{\circ} \mathrm{C}\left(\chi_{\text {water }}=1.2 \%\right)$.

In addition to continuous measurement of the laser power throughout the field experiments, the instrument's Raman scattering sensitivity was measured nightly by overflowing the inlet with zero air and gradually increasing the cell pressure. The slope of the plot of PMT counts $s^{-1}$ versus cell pressure quantified the $\mathrm{O}_{2}$ Raman scattering at $739 \mathrm{~nm}$ (the Q-branch of the $\mathrm{N}_{2}$ Stokes Raman scattering occurs on the long wavelength side of the $750 \mathrm{~nm}$ short-pass filter). Variations in the $\mathrm{O}_{2}$ Raman scattering intensity were used to track any changes in the optical collection efficiency of the instrument. The in-field calibration constant for each night was deduced by examination of the laser power and this Raman slope. During the course of the experiment ( $\sim 1$ month), the laser power decreased from 333 to $108 \mathrm{~mW}$ and the calibration constant decreased from 86 to 28 counts $\mathrm{s}^{-1} \mathrm{ppbv}^{-1}$. With a background of 110 counts/s and a calibration constant of 43 counts $\mathrm{s}^{-1} \mathrm{ppbv}^{-1}$ (typical values for the measurements presented in the results section below), the detection limit for $\mathrm{N}_{2} \mathrm{O}_{5}$ was $28 \mathrm{pptv}$ in a $10 \mathrm{~min}$ integration (signalto-noise $=2$ ). The total uncertainty was estimated to be under $15 \%$.

\subsection{Other measurements}

$\mathrm{NO}_{2}$ was measured by laser-induced fluorescence using the instrument described by Cleary et al (Cleary et al., 2002). Briefly, ambient air was transported through four meters of $1 / 4^{\prime \prime}$ OD PFA Teflon tubing to the instrument which was housed inside the observatory. Air was pumped through a $350 \mu \mathrm{m}$ orifice into a chamber held at $300 \mathrm{mTorr}$, producing a supersonic expansion. Light from a $6 \mathrm{~mW}$ tunable diode laser (TUI optics) at $640 \mathrm{~nm}$ excited the rotationally cooled $\mathrm{NO}_{2}$ in the $\left(A^{2} \mathrm{~B}_{2} \leftarrow X^{2} \mathrm{~A}_{1}\right)$ transition. The laser light intersected the supersonic expansion $\sim 1 \mathrm{~cm}$ downstream of the nozzle in a 72-pass Herriott cell alignment. Fluorescence to the red of $750 \mathrm{~nm}$ was detected by a GaAs PMT. The accuracy and detection limit of this instrument were $5 \%$ and 140 pptv (60-s average, signal-to-noise=2), respectively. The decrease in laser power since the publication of Cleary et al ( $6 \mathrm{~mW}$ vs $16 \mathrm{~mW}$ ) was offset by the discovery of an $\mathrm{NO}_{2}$ line with twice the intensity of that previously used.

Ozone was measured by absorption of $254 \mathrm{~nm}$ light using a Dasibi 1008-RS analyzer, which had an accuracy of $1 \%$ and a detection limit of 1 ppbv with 1 min averaging. Relative humidity, wind direction and speed were measured with 


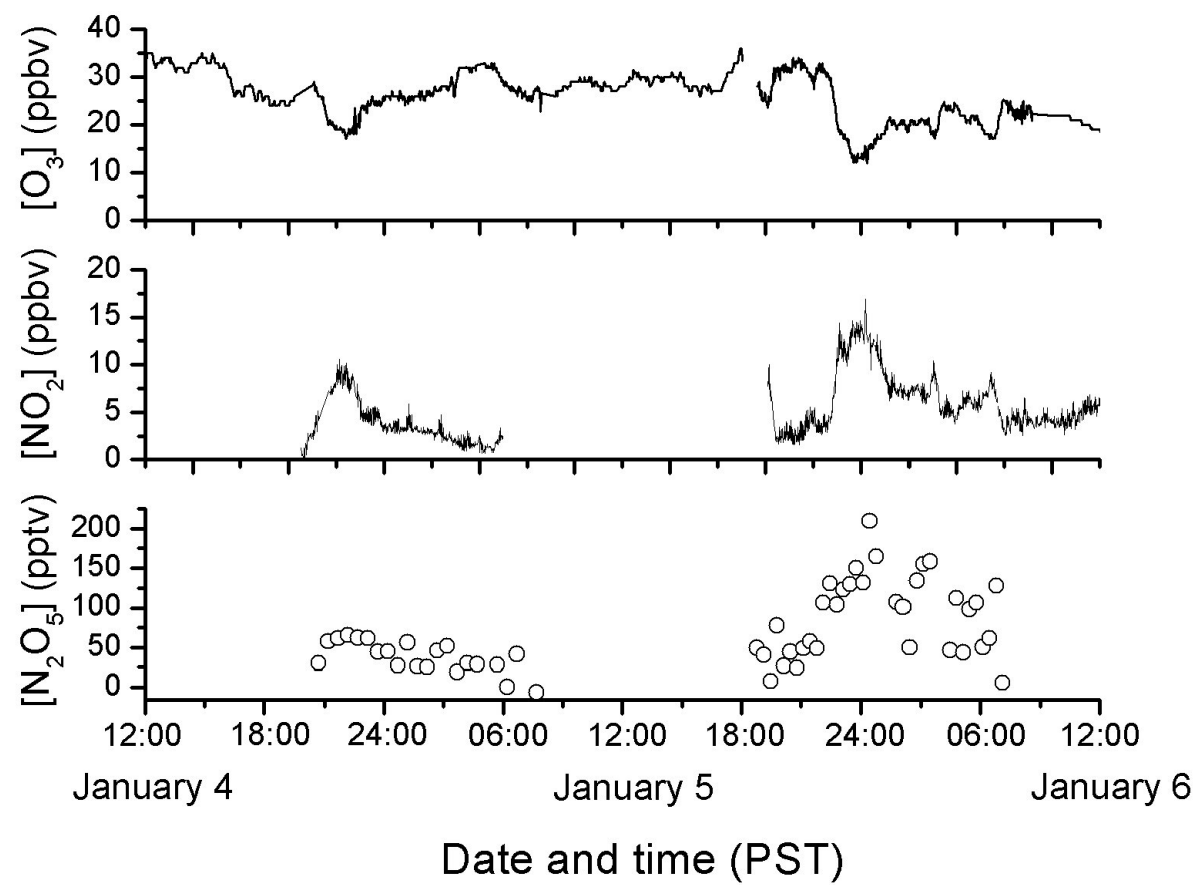

Fig. 3. Time series of $\left[\mathrm{O}_{3}\right]$ ( $1 \mathrm{~min}$ average), $\left[\mathrm{NO}_{2}\right]$ (30 s average), and $\left[\mathrm{N}_{2} \mathrm{O}_{5}\right]$ (30 min average) from 4 January $2004-6$ January 2004.

a Texas Weather instruments WR-25 weather station on the roof of the observatory. Air temperature was measured $15 \mathrm{~m}$ outside the observatory.

\section{Results}

Measurements were taken on six nights during January 2004. Temperatures ranged from $2^{\circ}-12^{\circ} \mathrm{C}$ with the relative humidity usually between $70 \%$ and $100 \%$ (fog). Winds were usually calm (less than $2 \mathrm{~m} / \mathrm{s}$ ) and had no regular direction. $\mathrm{N}_{2} \mathrm{O}_{5}$ mixing ratios were above the detection limit (6 pptv in a $1 \mathrm{~h}$ integration at full laser power) on only a few of these nights, and were at most 200 pptv. The nights when $\left[\mathrm{N}_{2} \mathrm{O}_{5}\right]$ was below the detection limit were characterized by either high relative humidity ( $>90 \%$, occasionally foggy), ozone mixing ratios below 12 ppbv, or uncharacteristically low $\mathrm{NO}_{2}$ mixing ratios $(<1 \mathrm{ppbv})$.

A time series of $\mathrm{NO}_{2}, \mathrm{O}_{3}$, and $\mathrm{N}_{2} \mathrm{O}_{5}$ for the nights of 4 and 5 January is shown in Fig. 3. On the night of the 4th the temperature was $3 \pm 1{ }^{\circ} \mathrm{C}$, the relative humidity was $70-75 \%$, the wind speed was $0-2 \mathrm{~m} / \mathrm{s}$ and the wind direction was variable. On the night of the 5 th the temperature was $6.5 \pm 0.5^{\circ} \mathrm{C}$ with $1-2 \mathrm{~m} / \mathrm{s}$ winds from the north/northeast giving way to westerly winds shortly before midnight. The relative humidity increased shortly after this change in wind direction from $55 \%$ to $73 \%$. Ozone mixing ratios varied from $15-35 \mathrm{ppbv}$ and $\mathrm{N}_{2} \mathrm{O}_{5}$ ranged up to 200 pptv during these two nights. The observed scatter in the $\mathrm{N}_{2} \mathrm{O}_{5}$ time series is a combination of atmospheric variability and instrumental noise (the $1 \sigma$ preci- sion for 30 min averages is 9 pptv). The highest $\mathrm{N}_{2} \mathrm{O}_{5}$ concentrations were observed during the transit of plumes observed from 20:30-24:00 Pacific Standard Time (PST) on 4 January and 20:30-04:20 PST on 5 and 6 January that exhibited high $\mathrm{NO}_{2}$ and low $\mathrm{O}_{3}$ concentrations. $\mathrm{N}_{2} \mathrm{O}_{5}$ concentrations decayed to zero shortly after local sunrise at 07:20 PST on the morning of 6 January. Instrumental failures prevented measurement of $\mathrm{N}_{2} \mathrm{O}_{5}$ or $\mathrm{NO}_{2}$ during sunrise on 5 January. Measurements did not resume until the evening of 5 January.

The quantity $\mathrm{F}\left(\mathrm{NO}_{\mathrm{SUM}}\right)$, using the terminology of Brown et al. (2003a), represents the fraction of reactive nitrogen oxides in the form of $\mathrm{N}_{2} \mathrm{O}_{5}$ or $\mathrm{NO}_{3}$ and is defined as $\left(\left[\mathrm{NO}_{3}\right]+2\left[\mathrm{~N}_{2} \mathrm{O}_{5}\right]\right) /\left([\mathrm{NO}]+\left[\mathrm{NO}_{2}\right]+\left[\mathrm{NO}_{3}\right]+2\left[\mathrm{~N}_{2} \mathrm{O}_{5}\right]\right)$. At these low $\mathrm{NO}_{3}$ concentrations and in the assumed absence of $\mathrm{NO}, \mathrm{F}\left(\mathrm{NO}_{\mathrm{SUM}}\right)$ is equal to $2\left[\mathrm{~N}_{2} \mathrm{O}_{5}\right] /\left(2\left[\mathrm{~N}_{2} \mathrm{O}_{5}\right]+\left[\mathrm{NO}_{2}\right]\right)$ and was usually in the range $0.01-0.04$.

Given ample time, a pseudo steady state is formed between the production of $\mathrm{NO}_{3}$ and $\mathrm{N}_{2} \mathrm{O}_{5}$ and their losses (e.g. hydrolysis of $\mathrm{N}_{2} \mathrm{O}_{5}$ ). The $\mathrm{N}_{2} \mathrm{O}_{5}$ steady state lifetime is defined as

$\tau_{S S}\left(\mathrm{~N}_{2} \mathrm{O}_{5}\right)=\frac{\left[\mathrm{N}_{2} \mathrm{O}_{5}\right]}{\mathrm{k}_{1}\left[\mathrm{NO}_{2}\right]\left[\mathrm{O}_{3}\right]}$

In the absence of direct $\mathrm{NO}_{3}$ losses, this lifetime is equal to the reciprocal of the first order $\mathrm{N}_{2} \mathrm{O}_{5}$ loss rate constant as described by Brown et al. (2003b). Direct losses of $\mathrm{NO}_{3}$ are not expected to be significant since the scavengers of $\mathrm{NO}_{3}$ were expected to be scarce: $\mathrm{NO}$ is converted to $\mathrm{NO}_{2}$ at night by reaction with $\mathrm{O}_{3}$, and biogenic hydrocarbons are not expected in significant concentrations at this site in winter. 
The pseudo steady state lifetimes of $\mathrm{N}_{2} \mathrm{O}_{5}$ calculated from the measurements on the nights of 4 and 5 January range from 10 to $30 \mathrm{~min}$. Although it is possible for the steady state to be disrupted by NO emissions, this was unlikely. The nearest significant $\mathrm{NO}_{\mathrm{x}}$ source was highway 24, which is $3 \mathrm{~km}$ south of the site. At a speed of $2 \mathrm{~m} / \mathrm{s}$ it would take $25 \mathrm{~min}$ for such air to reach the site, a time comparable to that required for the formation of the steady state. Also, since traffic on highway 24 was low at night and winds were rarely observed from the south, the more likely $\mathrm{NO}_{\mathrm{x}}$ sources were from the more distant power plants to the north of the site (e.g. in Martinez, $10 \mathrm{~km}$ away). Soil emissions of NO were unlikely due to the cold temperatures (Meixner and Yang, 2004). If there were a small NO source close to the measurement site, however, the $\mathrm{N}_{2} \mathrm{O}_{5}$ lifetimes calculated by Reaction (6) would be underestimates of the true $\mathrm{N}_{2} \mathrm{O}_{5}$ lifetime due to hydrolysis. As an estimate of the potential error from this term, we calculate the effect of a high concentration of NO, $10 \mathrm{pptv}$, on the calculated lifetime of $\mathrm{N}_{2} \mathrm{O}_{5}$. For an $\mathrm{N}_{2} \mathrm{O}_{5}$ loss rate constant of $(20 \mathrm{~min})^{-1}$ with initial values of $\left[\mathrm{NO}_{2}\right]$ of $8 \mathrm{ppbv}$ and $\left[\mathrm{O}_{3}\right]$ of $25 \mathrm{ppbv}$, we find that the lifetime calculated using Reaction (6) would be in error by $\approx 15 \%$. Anthropogenic alkenes would have to exist in unrealistically high concentrations to have a comparable effect since their rate constants for reaction with $\mathrm{NO}_{3}$ are orders of magnitude slower than the rate constant for the reaction of $\mathrm{NO}$ with $\mathrm{NO}_{3}$. For example, $30 \mathrm{ppbv}$ of propene would be required to have the equivalent effect of 10 pptv of NO.

Strong vertical concentration gradients caused by the emission of NO, as observed by DOAS (Stutz et al., 2004), are not likely here in the absence of a nearby NO source. Any vertical gradient produced in an air parcel at the distant NO sources would most likely have disappeared during advection to the measurement site. However, it is possible that direct deposition to the surface could be a sink of $\mathrm{N}_{2} \mathrm{O}_{5}$ that contributes to a vertical gradient, although we calculate that the $\mathrm{N}_{2} \mathrm{O}_{5}$ lifetime with respect to deposition is several hours, which is an order of magnitude longer than the lifetime we infer from the observations.

On nights when the $\mathrm{N}_{2} \mathrm{O}_{5}$ mixing ratios were below the detection limit, an upper limit can be calculated for $\tau_{S S}\left(\mathrm{~N}_{2} \mathrm{O}_{5}\right)$. For example, on 10 and 11 January, $\left[\mathrm{NO}_{2}\right]$ was on average $1.5 \mathrm{ppbv},\left[\mathrm{O}_{3}\right]$ was $31 \mathrm{ppbv}$, and the relative humidity was $89 \%$. Assuming a maximum $\mathrm{N}_{2} \mathrm{O}_{5}$ mixing ratio of $6 \mathrm{pptv}$, the calculated steady state lifetime was at most $5 \mathrm{~min}$. The aerosol scattering this night, as measured by the pressure dependence of the instrument's background, was twice that measured the night of the 4 th.

\section{Discussion}

The pseudo steady state lifetime of $\mathrm{N}_{2} \mathrm{O}_{5}$ is an indication of the role of $\mathrm{NO}_{3}$ and $\mathrm{N}_{2} \mathrm{O}_{5}$ in an air mass. Long lifetimes indicate that $\mathrm{N}_{2} \mathrm{O}_{5}$ is relatively unreactive and is mainly a nocturnal reservoir of $\mathrm{NO}_{\mathrm{x}}$, re-forming $\mathrm{NO}_{\mathrm{x}}$ in the morning after thermal decomposition of $\mathrm{N}_{2} \mathrm{O}_{5}$ and subsequent photolysis of $\mathrm{NO}_{3}$. Shorter lifetimes indicate higher reactivity of $\mathrm{N}_{2} \mathrm{O}_{5}$ and its role as a sink for $\mathrm{NO}_{\mathrm{x}}$. Correlations of the pseudo steady state lifetime with relative humidity and aerosol load have been used at numerous locations to infer the mechanism of $\mathrm{N}_{2} \mathrm{O}_{5}$ loss. At a site near Boulder, Colorado in November of 2001, Brown and co-workers observed $\mathrm{N}_{2} \mathrm{O}_{5}$ in an urban plume with $\left[\mathrm{NO}_{2}\right]$ and $\left[\mathrm{O}_{3}\right]$ comparable to those we report here (Brown et al., 2003a, b). Their observed $\mathrm{N}_{2} \mathrm{O}_{5}$ mixing ratios were much larger $\left(\mathrm{F}\left(\mathrm{NO}_{\mathrm{SUM}}\right)\right.$ up to 0.25$)$ than observed at Leuschner, and calculations using their data give an $\mathrm{N}_{2} \mathrm{O}_{5}$ steady state lifetime of approximately $2 \mathrm{~h}$. The measurement site in Colorado was typically characterized by relative humidity values below $60 \%$ at night.

In the marine boundary layer off the coast of New England during the summer of 2002, $\mathrm{N}_{2} \mathrm{O}_{5}$ mixing ratios measured by Brown et al were much smaller ( $<200$ pptv) and $\mathrm{F}\left(\mathrm{NO}_{\mathrm{SUM}}\right)$ was on average 0.05 (Brown et al., 2004). The $\mathrm{N}_{2} \mathrm{O}_{5}$ pseudo steady state lifetime was on order $30 \mathrm{~min}$ to $1 \mathrm{~h}$, in an environment in which there were significant losses of $\mathrm{NO}_{3}$ due to reaction with dimethyl sulfide and biogenic hydrocarbons (Warneke et al., 2004).

Using measurements of $\mathrm{NO}_{3}, \mathrm{NO}_{2}, \mathrm{O}_{3}$, and the aerosol size distribution in Helgoland, Germany during October 1996, Martinez et al inferred the $\mathrm{N}_{2} \mathrm{O}_{5}$ pseudo steady state lifetime and demonstrated a negative correlation with the aerosol load (Martinez et al., 2000). The $\mathrm{N}_{2} \mathrm{O}_{5}$ steady state lifetimes ranged from 8 to $15 \mathrm{~min}$ at aerosol surface area values of $500-700 \mu \mathrm{m}^{2} \mathrm{~cm}^{-3}$ and $15 \mathrm{~min}$ to $120 \mathrm{~min}$ at aerosol surface areas less than $200 \mu \mathrm{m}^{2} \mathrm{~cm}^{-3}$. The negative correlation of $\tau_{S S}\left(\mathrm{~N}_{2} \mathrm{O}_{5}\right)$ with the average aerosol radius was more pronounced than that with aerosol surface area, which they attributed to the fact that the more $\mathrm{N}_{2} \mathrm{O}_{5}$-reactive deliquescent particles can grow to large diameters due to uptake of water.

$\mathrm{N}_{2} \mathrm{O}_{5}$ steady state lifetimes were calculated from observations of $\mathrm{NO}_{3}, \mathrm{NO}_{2}$, and $\mathrm{O}_{3}$ at a rural site in the Baltic Sea over a period of 14 months (Heintz et al., 1996). The $\mathrm{N}_{2} \mathrm{O}_{5}$ steady state lifetimes varied from $17 \mathrm{~min}$ to over $5 \mathrm{~h}$, though they were usually under an hour. Additionally, a negative correlation between the $\mathrm{NO}_{3}$ lifetime and $\left[\mathrm{NO}_{2}\right]$, which is usually presented as evidence of the predominance of $\mathrm{N}_{2} \mathrm{O}_{5}$ loss over $\mathrm{NO}_{3}$ loss mechanisms (Geyer et al., 2001; Martinez et al., 2000), was only found to exist for relative humidities above $58 \%$.

Heterogeneous loss of $\mathrm{N}_{2} \mathrm{O}_{5}$ on the surface of aerosols is expected to be an important sink in the conditions observed at the Leuschner Observatory. The relative humidity was usually greater than $75 \%$, which is near the deliquescence relative humidity of many common aerosol systems, suggesting that most aerosol particles were in the liquid phase. Uptake of $\mathrm{N}_{2} \mathrm{O}_{5}$ is in general much faster onto aqueous aerosol than onto solid aerosol (e.g. $\gamma\left(\mathrm{N}_{2} \mathrm{O}_{5}\right)$ onto $\left(\mathrm{NH}_{4}\right)_{2} \mathrm{SO}_{4}$ aerosol is 
$2 \times 10^{-3}$ at $20 \%$ relative humidity and $1.5 \times 10^{-2}$ at $70 \%$ relative humidity; Hallquist et al., 2003).

For aerosol radii less than $1 \mu \mathrm{m}$ the $\mathrm{N}_{2} \mathrm{O}_{5}$ loss rate constant $\left(k_{h e t}\right)$ due to heterogeneous uptake onto aerosol can be expressed as

$k_{h e t}=\tau^{-1}\left(\mathrm{~N}_{2} \mathrm{O}_{5}\right)=\gamma A \bar{c} / 4$

where $\gamma$ is the uptake coefficient of $\mathrm{N}_{2} \mathrm{O}_{5}$ and is a function of the aerosol composition, $A$ is the surface area density, and $\bar{c}$ is the mean molecular speed of $\mathrm{N}_{2} \mathrm{O}_{5}$. At $279 \mathrm{~K}$, a lifetime of 20 min with a $\gamma$ of 0.07 corresponds to an aerosol surface area density of $200 \mu \mathrm{m}^{2} \mathrm{~cm}^{-3}$, a reasonable estimate and one consistent with the relationships between the $\mathrm{N}_{2} \mathrm{O}_{5}$ lifetime and aerosol load observed by Martinez et al. The low $\mathrm{N}_{2} \mathrm{O}_{5}$ concentrations and short lifetimes $(<5 \mathrm{~min})$ observed at the Leuschner Observatory on nights of high relative humidity $(>90 \%)$ are consistent with a reactive high surface area due to the growth of deliquescent particles by uptake of water.

As a result of the short $\mathrm{N}_{2} \mathrm{O}_{5}$ lifetime, nearly all of the $\mathrm{NO}_{2}$ converted to $\mathrm{NO}_{3}$ and $\mathrm{N}_{2} \mathrm{O}_{5}$ by Reactions (1) and (2) will be irreversibly converted to $\mathrm{HNO}_{3}$ during the night. The total amount of nitric acid produced over the course of the $14 \mathrm{~h}$ night can estimated by assuming that each molecule of $\mathrm{NO}_{3}$ formed by Reaction (1) will react to form $\mathrm{N}_{2} \mathrm{O}_{5}$, which in turn hydrolyzes to form two molecules of $\mathrm{HNO}_{3}$. The total $\mathrm{HNO}_{3}$ is then equal to twice the integrated rate of Reaction (1):

$$
\left[\mathrm{HNO}_{3}\right]_{\text {total }}=2 \int \frac{\left[\mathrm{N}_{2} \mathrm{O}_{5}\right]}{\tau_{S S}\left(\mathrm{~N}_{2} \mathrm{O}_{5}\right)} d t=2 \int \mathrm{k}_{\mathrm{NO}_{2}+\mathrm{O}_{3}}\left[\mathrm{NO}_{2}\right]\left[\mathrm{O}_{3}\right] d t
$$

Calculated $\left[\mathrm{HNO}_{3}\right]_{\text {total }}$ values ranged from $1.4 \mathrm{ppbv}$ to 5.9 ppbv during this experiment. For example, on the night of the 4 th, $\left[\mathrm{HNO}_{3}\right]_{\text {total }}$ was calculated to be $4.1 \mathrm{ppbv}$. Note that this is comparable to the average $\mathrm{NO}_{2}$ mixing ratio that night, indicating that this loss of $\mathrm{NO}_{\mathrm{x}}$ was balanced by fresh emissions on the regional scale.

The ratio of heterogeneous $\mathrm{HNO}_{3}$ production to that produced by the reaction of $\mathrm{OH}$ with $\mathrm{NO}_{2}$ during the day can be estimated:

$$
\frac{\int \mathrm{HNO}_{3} \text { (night) }}{\int \mathrm{HNO}_{3}(\text { day) }}=\frac{\int 2 \mathrm{k}_{\mathrm{NO}_{2}+\mathrm{O}_{3}}\left[\mathrm{NO}_{2}\right]\left[\mathrm{O}_{3}\right] d t}{\int \mathrm{k} \mathrm{OH}+\mathrm{NO}_{2}[\mathrm{OH}]\left[\mathrm{NO}_{2}\right] \mathrm{dt}}
$$

At the measurement site in January there was little difference between daytime and nighttime $\mathrm{NO}_{2}$ concentrations, and thus the $\mathrm{NO}_{2}$ term cancels out. Using the average nocturnal ozone mixing ratio of $25 \mathrm{ppbv}$, an estimated average daytime $\mathrm{OH}$ concentration of $3.4 \times 10^{5}$ molecules $\mathrm{cm}^{-3}$ (Spivakovsky et al., 2000), values of $1.7 \times 10^{-17} \mathrm{~cm}^{3}$ molecule ${ }^{-1} \mathrm{~s}^{-1}$ for $\mathrm{k}_{\mathrm{NO} 2+\mathrm{O} 3}$ and $10^{-11} \mathrm{~cm}^{3}$ molecule $\mathrm{s}^{-1} \mathrm{~s}^{-1}$ as the effective bimolecular rate constant for $\mathrm{k}_{\mathrm{OH}+\mathrm{NO} 2}$ at $279 \mathrm{~K}$, and integrating over $14 \mathrm{~h}$ for the night and $10 \mathrm{~h}$ for the day yields a ratio of 9 .

The nocturnal removal of $\mathrm{NO}_{\mathrm{x}}$ via $\mathrm{N}_{2} \mathrm{O}_{5}$ hydrolysis is likely occurring over a volume comparable to that under which the daytime removal of $\mathrm{NO}_{2}$ occurs during the winter. The lifetime of $\mathrm{NO}_{2}$ due to reaction with $3.4 \times 10^{5}$ molecules $\mathrm{cm}^{-3} \mathrm{OH}$ is 3 days, and so most daytime $\mathrm{NO}_{2}$ will persist into the residual layer at night, where it can undergo the same chemistry as observed in the nocturnal boundary layer. Thus differences in boundary layer height between day and night are unlikely to affect the significance of the ratio calculated in Reaction (9). This is in contrast to expectations for summer when the daytime concentration of $\mathrm{OH}$ is likely an order of magnitude higher, reducing the lifetime of $\mathrm{NO}_{2}$ to reaction with $\mathrm{OH}$ to less than $10 \mathrm{~h}$. Thus much less $\mathrm{NO}_{2}$ will persist into the residual layer, and $\mathrm{N}_{2} \mathrm{O}_{5}$ hydrolysis will be limited to the nocturnal boundary layer, lowering its overall importance.

\section{Conclusions}

Measurements of $\mathrm{N}_{2} \mathrm{O}_{5}, \mathrm{NO}_{2}$, and $\mathrm{O}_{3}$ at the University of California Russell Reservation in Contra Costa County, California indicate that $\mathrm{N}_{2} \mathrm{O}_{5}$ is very reactive at this location, with the steady state lifetimes for $\mathrm{N}_{2} \mathrm{O}_{5}$ no longer than $30 \mathrm{~min}$. Heterogeneous hydrolysis to form $\mathrm{HNO}_{3}$ is the most likely loss process, and thus formation of $\mathrm{NO}_{3}$ and $\mathrm{N}_{2} \mathrm{O}_{5}$ represents a sink of $\mathrm{NO}_{\mathrm{x}}$ since $\mathrm{HNO}_{3}$ is rapidly removed from the atmosphere by wet or dry depostion. Future measurements of $\mathrm{N}_{2} \mathrm{O}_{5}$ alongside an extended suite of complementary measurements including NO, VOCs, aerosol composition and size, and $\mathrm{HNO}_{3}$ will allow for a more quantitative understanding of the individual losses of $\mathrm{NO}_{3}$ and $\mathrm{N}_{2} \mathrm{O}_{5}$ and the subsequent fate of $\mathrm{HNO}_{3}$. Other issues to be explored include the oxidation of VOCs by $\mathrm{NO}_{3}$ during the warmer seasons to form alkyl nitrates (measurable by TD-LIF; Day et al., 2002) and the role of $\mathrm{NO}_{3}$ and $\mathrm{N}_{2} \mathrm{O}_{5}$ as a sink of odd oxygen, $\mathrm{O}_{\mathrm{x}}\left(\mathrm{O}_{\mathrm{x}} \equiv \mathrm{O}_{3}+\mathrm{NO}_{2}+2 \mathrm{NO}_{3}+3 \mathrm{~N}_{2} \mathrm{O}_{5}\right)$.

Although this first field test of our $\mathrm{N}_{2} \mathrm{O}_{5}$ LIF instrument was succesful, the time-varying component of the instrument background caused by aerosol scattering precluded its use at conditions of high aerosol load. Future improvements to the instrument, foremost the implementation of pulsed excitation and delayed time-gated detection, will eliminate this component and reduce other components of the background, enabling measurement of $\mathrm{N}_{2} \mathrm{O}_{5}$ and possibly $\mathrm{NO}_{3}$ in a wider range of environments.

Acknowledgements. We thank J. Graham of the University of California-Berkeley Astronomy department for help in choosing a measurement site, C. Bresloff for coordinating our use of the Leuschner Observatory, and A. Goldstein of the Environmental Science, Policy, and Management department for the loan of the Dasibi ozone monitor. This work was funded by NSF grant No. 0138669.

Edited by: A. Hofzumahaus 


\section{References}

Brown, S. S., Stark, H., Ciciora, S. J., McLaughlin, R. J., and Ravishankara, A. R.: Simultaneous in situ detection of atmospheric $\mathrm{NO}_{3}$ and $\mathrm{N}_{2} \mathrm{O}_{5}$ via cavity ring-down spectroscopy, Rev. Sci. Ins., 73 (9), 3291-3301, 2002.

Brown, S. S., Stark, H., Ryerson, T. B., Williams, E. J., Nicks, D. K., Trainer, M., Fehsenfeld, F. C., and Ravishankara, A. R.: Nitrogen oxides in the nocturnal boundary layer: Simultaneous in situ measurements of $\mathrm{NO}_{3}, \mathrm{~N}_{2} \mathrm{O}_{5}, \mathrm{NO}_{2}, \mathrm{NO}$, and $\mathrm{O}_{3}, \mathrm{~J}$. Geophys. Res.-A, 108 (D9), 4299, doi:10.1029/2002JD002917, 2003a.

Brown, S. S., Stark, H., and Ravishankara, A. R.: Applicability of the steady state approximation to the interpretation of atmospheric observations of $\mathrm{NO}_{3}$ and $\mathrm{N}_{2} \mathrm{O}_{5}$, J. Geophys. Res.-A, 108 (D17), 4539, doi:10.1029/2003JD003407, 2003b.

Brown, S. S., Dibb, J. E., Stark, H., Aldener, M., Vozella, M., Whitlow, S., Williams, E. J., Lerner, B. M., Jakoubek, R., Middlebrook, A. M., DeGouw, J. A., Warneke, C., Goldan, P. D., Kuster, W. C., Angevine, W. M., Sueper, D. T., Quinn, P. K., Bates, T. S., Meagher, J. F., Fehsenfeld, F. C., and Ravishankara, A. R.: Nighttime removal of $\mathrm{NO}_{\mathrm{x}}$ in the summer marine boundary layer, Geophys. Res. Lett., 31 (8), L07108, doi:10.1029/2004GL019412, 2004.

Carslaw, N., Plane, J. M. C., Coe, H., and Cuevas, E.: Observations of the nitrate radical in the free troposphere at Izana de Tenerife, J. Geophys. Res., 102 (D9), 10 613-10 622, 1997.

Cleary, P. A., Wooldridge, P. J., and Cohen, R. C.: Laser-induced fluorescence detection of atmospheric $\mathrm{NO}_{2}$ with a commercial diode laser and a supersonic expansion, Appl. Opt., 41 (33), 6950-6956, 2002.

Day, D. A., Wooldridge, P. J., Dillon, M. B., Thornton, J. A., and Cohen, R. C.: A thermal dissociation laser-induced fluorescence instrument for in situ detection of $\mathrm{NO}_{2}$, peroxy nitrates, alkyl nitrates, and $\mathrm{HNO}_{3}$, J. Geophys. Res.-A, 107 (D5-D6), art. no. 4046, doi:10.1029/2001JD000779, 2002.

Geyer, A., Alicke, B., Mihelcic, D., Stutz, J., and Platt, U.: Comparison of tropospheric $\mathrm{NO}_{3}$ radical measurements by differential optical absorption spectroscopy and matrix isolation electron spin resonance, J. Geophys. Res.-A, 104 (D21), 26 097-26 105, 1999.

Geyer, A., Ackermann, R., Dubois, R., Lohrmann, B., Muller, T., and Platt, U.: Long-term observation of nitrate radicals in the continental boundary layer near Berlin, Atmos. Envir., 35 (21), 3619-3631, 2001.

Hallquist, M., Stewart, D. J., Stephenson, S. K., and Cox, R. A.: Hydrolysis of $\mathrm{N}_{2} \mathrm{O}_{5}$ on sub-micron sulfate aerosols, Phys. Chem. Chem. Phys., 5 (16), 3453-3463, 2003.

Hanson, D. R. and Ravishankara, A. R.: The Reaction Probabilities of $\mathrm{ClONO}_{2}$ and $\mathrm{N}_{2} \mathrm{O}_{5}$ on 40-Percent to 75-Percent SulfuricAcid-Solutions, J. Geophys. Res.-A, 96 (D9), 17 307-17314, 1991.

Heintz, F., Platt, U., Flentje, H., and Dubois, R.: Long-term observation of nitrate radicals at the Tor Station, Kap Arkona (Ruegen), J. Geophys. Res., 101 (D17), 22 891-22 910, 1996.

Johnston, H. S., Davis, H. F., and Lee, Y. T.: $\mathrm{NO}_{3}$ Photolysis Product Channels - Quantum Yields From Observed Energy Thresholds, J. Phys. Chem., 100 (12), 4713-4723, 1996.

Kunde, V. G., Brasunas, J. C., Maquire, W. C., Herman, J. R., Massie, S. T., Abbas, M. M., Herath, L. W., and Shaffer, W. A.:
Measurement of Nighttime Stratospheric $\mathrm{N}_{2} \mathrm{O}_{5}$ from Infrared Emission Spectra, Geophys. Res. Lett., 15, 1177-1180, 1988.

Martinez, M., Perner, D., Hackenthal, E. M., Kulzer, S., and Schutz, L.: $\mathrm{NO}_{3}$ at Helgoland during the NORDEX campaign in October 1996, J. Geophys. Res.-A, 105 (D18), 22 685-22 695, 2000.

Mentel, T. F., Sohn, M., and Wahner, A.: Nitrate effect in the heterogeneous hydrolysis of dinitrogen pentoxide on aqueous aerosols, Phys. Chem. Chem. Phys., 1 (24), 5451-5457, 1999.

Meixner, F. and Yang, W.: Biogenic Emissions of Nitric Oxide and Nitrous Oxide from Arid and Semi-Arid Land, Kluwer Academic Publishers, The Netherlands, 2004.

Platt, U. and Heintz, F.: Nitrate Radicals in Tropospheric Chemistry, Isr. J. Chem., 34 (3-4), 289-300, 1994.

Rinsland, C. P., Toon, G. C., Farmer, C. B., Norton, R. H., and Namkung, J. S.: Stratospheric $\mathrm{N}_{2} \mathrm{O}_{5}$ profiles at sunrise and sunset from further analysis of the ATMOS/Spacelab 3 solar spectra, J. Geophys. Res., 94 (D15), 18 341-18349, 1989.

Robinson, G. N., Worsnop, D. R., Jayne, J. T., Kolb, C. E., and Davidovits, P.: Heterogeneous uptake of $\mathrm{ClONO}_{2}$ and $\mathrm{N}_{2} \mathrm{O}_{5}$ by sulfuric acid solutions, J. Geophys. Res., 102 (D3), 3583-3601, 1997.

Sander, S. P., Friedl, R. R., Golden, D. M., Kurylo, M. J., Huie, R. E., Orkin, V. L., Moortgat, G. K., Ravishankara, A. R., Kolb, C. E., Molina, M. J., and Finlayson-Pitts, B. J.: Chemical Kinetics and Photochemical Data for Use in Atmospheric Studies, JPL Publication 02-25, Evaluation Number 14, 2003.

Sen, B., Toon, G. C., Osterman, G. B., Blavier, J. F., Margitan, J. J., Salawitch, R. J., and Yue, G. K.: Measurements of reactive nitrogen in the stratosphere, J. Geophys. Res.-A, 103 (D3), 3571-3585, 1998.

Simpson, W. R.: Continuous wave cavity ring-down spectroscopy applied to in situ detection of dinitrogen pentoxide $\left(\mathrm{N}_{2} \mathrm{O}_{5}\right)$, Rev. Sci. Ins., 74 (7), 3442-3452, 2003.

Spivakovsky, C. M., Logan, J. A., Montzka, S. A., Balkanski, Y. J., Foreman-Fowler, M., Jones, D. B. A., Horowitz, L. W., Fusco, A. C., Brenninkmeijer, C. A. M., Prather, M. J., Wofsy, S. C., and McElroy, M. B.: Three-dimensional climatological distribution of tropospheric OH: Update and evaluation (Review), J. Geophys. Res.-A, 105 (D7), 8931-8980, 2000.

Stutz, J., Alicke, B., Ackermann, R., Geyer, A., White, A., and Williams, E.: Vertical Profiles of $\mathrm{NO}_{3}, \mathrm{~N}_{2} \mathrm{O}_{5}, \mathrm{O}_{3}$, and $\mathrm{NO}_{\mathrm{x}}$ in the nocturnal boundary layer: 1. Observations during the Texas Air Quality Study 2000, J. Geophys. Res., 109 (D12306), doi:10.1029/2003JD004209, 2004.

Toon, G. C., Farmer, C. B., and Norton, R. H.: Detection of stratospheric $\mathrm{N}_{2} \mathrm{O}_{5}$ by infrared remote sounding, Nature, 319, 570$571,1986$.

Warneke, C., de Gouw, J. A., Goldan, P. D., Kuster, W. C., Williams, E. J., Lerner, B. M., Jakoubek, R., Brown, S. S., Stark, H., Aldener, M., Ravishankara, A. R., Roberts, M., Marchewka, M., Bertman, S., Sueper, D. T., McKeen, S. A., Meagher, J. F., and Fehsenfeld, F. C.: Comparison of daytime and nighttime oxidation of biogenic and anthropogenic VOCs along the New England coast in summer during New England Air Quality Study 2002, J. Geophys. Res., 109 (D10), D10309, doi:10.1029/2003JD004424, 2004.

Wayne, R. P., Barnes, I., Biggs, P., Burrows, J. P., Canosa-Mas, C. E., Hjorth, J., Le Bras, G., Moortgat, G. K., Perner, D., Poulet, G., Restelli, G., and Sidebottom, H.: The nitrate radical: physics, 
E. C. Wood et al.: Measurements of $\mathrm{N}_{2} \mathrm{O}_{5}, \mathrm{NO}_{2}$, and $\mathrm{O}_{3}$ east of the San Francisco Bay

chemistry, and the atmosphere, Atmos. Envir., Part A (General Topics), 25A (1), 1-203, 1991.

Wood, E. C., Wooldridge, P. J., Freese, J. H., Albrecht, T., and Cohen, R. C.: Prototype for in situ detection of atmospheric $\mathrm{NO}_{3}$ and $\mathrm{N}_{2} \mathrm{O}_{5}$ via laser-induced fluorescence, Env. Sci. Tech., 37 (24), 5732-5738, 2003.
Zhou, D. K., Bingham, G. E., Rezai, B. K., Anderson, G. P., Smith, D. R., and Nadile, R. M.: Stratospheric $\mathrm{CH}_{4}, \mathrm{~N}_{2} \mathrm{O}, \mathrm{H}_{2} \mathrm{O}, \mathrm{NO}_{2}$, $\mathrm{N}_{2} \mathrm{O}_{5}$, and $\mathrm{ClONO}_{2}$ profiles retrieved from cryogenic infrared radiance instrumentation for shuttle (CIRRIS 1A)/STS 39 measurements, J. Geophys. Res.-A, 102 (D3), 3559-3573, 1997. 